\title{
DETERMINANTS OF ACCOUNTING CHOICES IN EGYPT
}

\author{
C.R. Dey \\ J.R. Grinyer \\ C.D. Sinclair \\ H. El-Habashy*
}

School of Accountancy and Business Finance

University of Dundee

UK

* Faculty of Commerce

Menoufia University

Egypt

Address for correspondence:

Dr C.R. Dey

School of Accountancy and Business Finance

University of Dundee

Dundee

DD1 4HN

E-mail: c.r.dey@dundee.ac.uk

Phone: +44 1382384193

Published in Journal of Applied Accounting Research by Emerald. The published version is available at: http://dx.doi.org/10.1108/96754260880001054 


\title{
DETERMINANTS OF ACCOUNTING CHOICE IN EGYPT
}

\begin{abstract}
In recent years, Egypt has been developing rapidly from a socialist to a fully developed market-based economy. One may expect that this economic transition towards a more capitalist orientation will influence the country's cultural and socio-economic environment, and consequently the behaviour of its corporate managers. The increasing separation of ownership and control of capital could be expected to increase agency problems associated with managerial decisions. In these circumstances, it should be interesting to identify whether 'positive accounting' hypotheses would apply in such an environment. Therefore, this paper examines the relevance to financial reporting in Egypt of some established positive accounting theory hypotheses in addition to a new hypothesis related to taxation. The evidence of the study is consistent with the validity of the conventional 'bonus' and 'debt' hypotheses and the new 'taxation' hypothesis. These conclusions are also consistent with recent empirical studies of cultural and socio-economic change in Egypt.
\end{abstract}

Keywords: Accounting choice, positive accounting theories, Egypt, developing capitalist economies. 


\section{INTRODUCTION}

Egypt is a predominantly Islamic country that since the mid-1980s has sought to replace its socialist planned economy and associated nationalised industries with a growing capitalist economy. This political and economic transition provides an interesting context within which the evolution of accounting practices and the behaviour of economic agents may be studied (see, for example, Gray et al., 1984; Doupnik and Salter, 1995; Brown and Humphreys, 1995; Humphreys, 1996; Abd-Elsalam and Weetman, 2003; HassabElnaby and Mosebach, 2005). Managers' behavior may be influenced by the ethical, cultural and institutional environments in which they operate. Some research has suggested that significant cultural differences may exist between Egyptian and Anglo-American corporate environments (Humphreys, 1996). Nevertheless, more recent research has argued that the changes in the Egyptian economy have been accompanied by significant changes in its national culture. It is reasoned that these changes have in turn produced a change in accounting choices, so that the latter are increasingly similar to those employed in developed market-based economies (HassabElnaby and Mosebach, 2005).

The precise nature of the relationship between national culture and managerial behaviour is complex, and beyond the scope of this paper. However, there is no doubt about the scale and significance of Egypt's transition towards a market-based economy in recent years. The process of reform has been accelerating since 1986, when the privatisation of the country's state-owned utilities was initiated. Since 1991, the Cairo stock market has been reopened, Egypt has joined the World Trade Organisation and it has also established international trade and investment agreements with the US and the European Union. Egypt therefore provides an especially interesting situation for testing the expectations of selfserving personal wealth maximizing behavior by individuals. One could reason that the maximisation of personal utility seems as likely to describe the motivation of Egyptian 
managers as it does of Western managers. This reasoning is adopted here, and leads to the hypothesis that, subject to dominating ethical and institutional constraints, Egyptian managers and investors would prefer more wealth to less wealth.

Nevertheless, it is probably necessary to recognise that the business environment in Egypt is still different in some important respects to that in established capitalist economies. More specifically, while Egypt's capital markets are developing rapidly, many large quoted and unquoted Egyptian businesses are owned and controlled by relatively small numbers of people. Consequently, a comparatively high proportion of businesses are owner-controlled relative to their counterparts in the USA or the UK (see PCSU, 2000; World Bank, 2001). This institutional factor might affect the behaviour of managers who are agents, because they are likely to be more closely monitored. Existing literature suggests that a relationship may be identified between the level of owners' control and (at least some) accounting choices (Dhaliwal et al., 1982; Abdel Khalik, 1985; Hunt, 1986; Penno and Simon, 1986; Niehaus, 1989; Carlson and Bathala, 1997). In contrast to their counterparts in closely held firms, managers of Egyptian companies with widely dispersed share ownership frequently face very little external supervision of their decisions (PCSU, 2000; World Bank, 2001). Thus, they might with impunity often pursue their own interests - even if these conflict with the objectives of shareholders.

Positive accounting theory (PAT) (Watts and Zimmerman, 1978; 1986) assumes that accounting choices are influenced by managerial opportunism. PAT researchers hypothesise that (a) to increase their own remuneration when it is based on accounting earnings and (b) to avoid violating debt covenants, managers will often prefer income-increasing accounting methods. These PAT hypotheses have been frequently tested in western industrialised countries (for a summary, see Fields et al., 2001), but their relevance to the economies of other countries is relatively less well researched. However, given the current socio-economic 
climate in Egypt, we believe that standard PAT hypotheses may be appropriate. Consequently, this paper is based on a hypothesis that the motivations and behaviour of Egyptian businessmen are similar to those of their Anglo-American counterparts and do not differ because of any cultural or institutional factors identified elsewhere in the literature referenced. Although the empirical evidence was obtained in Egypt, it may be argued that such evidence has wider significance for other Middle-Eastern countries with capitalist economies.

This paper therefore reasons that the empirical evidence in Egypt will be consistent with the conventional (a) bonus plan and (b) debt PAT hypotheses (see Watts and Zimmerman, 1986; 1990). In addition, the paper develops and tests a development of the hypothesis that managers will "make accounting choices in order to reduce their tax burden (and thus increase their cash flows)" (Fields et al., 2001, p.284). The derived hypothesis is that managers are more likely to choose accounting income increasing reporting methods that do not increase the current taxation charges on income than those that do increase those charges. This test is possible because of the Egyptian regulations for calculating taxable income, which are similar to those operating in the UK and the USA.

The reported empirical study follows conventional practice, because it uses an established database of financial information for firms quoted on the Egyptian stock market. However, that market is still small relative to Anglo-American counterparts. Consequently the study also analyses information from an independent questionnaire survey. This methodological expansion enables comparison of the findings from each independent source and allows the study to be extended to many large firms that are not quoted on the stock exchange as well as to companies that are too small to be listed. 


\section{DEVELOPMENT OF HYPOTHESES}

PAT considers the factors that influence managers' choices of accounting policies (Watts and Zimmerman, 1978; 1986; 1990) and suggests that managers will act opportunistically when their accounting choices have economic consequences. It has generated very extensive empirical research, detailed reviews of which are available elsewhere (see, for example, Fields et al., 2001). Accounting variables have economic consequences because remuneration and borrowing contracts often use such variables in an attempt to resolve agency conflicts (Holthausen and Leftwich, 1983). They also have economic consequences when they affect the computation of taxable income, because they then directly affect the timing of cash outflows from a business and consequently the availability of money to finance the firm's activities and its payments to participants in the business (Fields et al., 2001). PAT hypothesises that managers use their discretion to increase accounting profit in order to maximise their bonuses (the 'bonus plan hypothesis') and to avoid constraints associated with borrowing (the 'debt covenant hypothesis'). A further hypothesis is that managers accounting decisions will be affected by their impact on the amount or timing of payments for taxation (Fields et al., 2001). Increases in accounting income can often result in increases in current taxation, while one could expect rational managers to seek to avoid.

It is often assumed that current reported earnings can be increased by adopting: FIFO for inventory valuation; operating rather than capital leases; straight-line depreciation; and pooling-of-interests accounting. Increases in such earnings would frequently increase current earnings-based compensation and reduce the likelihood of breaching any contractual or implied accounting-based constraints associated with borrowing. Unfortunately, they may also increase current taxable income and therefore advance the time for payment of tax on earnings over the firm's lifetime, with adverse effects on financing. Consequently there may be conflicting motivations - some for increasing reported earnings, others for reducing such 
earnings.

\section{Bonus Plans Hypotheses}

The relationships between the existence of bonus plans and accounting policies have been extensively researched in Anglo-American economies. Evidence by Healy (1985), Gaver et al. (1995), Holthausen et al. (1995) and Guidry et al. (1999) suggests that managers in large firms managed by agents select accounting methods that transfer wealth to themselves from the firm's equity holders. Accounting earnings are expected to possess desirable characteristics not shared by other performance measures, including objectivity, reliability, verifiability and conservatism (Watts and Zimmerman, 1986). They may therefore provide a more appropriate basis for evaluating a manager's performance than alternative measures (Healy, 1985; Sloan, 1993; Dechow, 1994; Emanuel et al., 2003) ${ }^{1}$ and are extensively, but not exclusively, used for that purpose. Bonus schemes are one approach to reducing agency conflicts between a firm's managers and its owners by rewarding or punishing poor financial performance of managers (Smith and Watts, 1982; Healy, 1985; Watts and Zimmerman, 1986; Sloan, 1993). They are frequently based on accounting earnings, and it can be assumed that they are positively associated with earnings. A further assumption that executives will prefer higher to lower personal current income then leads to the conventional bonus hypothesis that, subject to the operation of contractual minimum income level constraints, managers with bonus schemes are more likely to choose current income-increasing accounting methods (Ittner et al., 1997, Zmijewski and Hagerman, 1981) ${ }^{2}$. Such choices would accelerate wealth transfers to the managers from the equity holders ${ }^{3}$.

It is possible that Egyptian managers' behaviour is constrained by their specific socioeconomic environment (Humphreys, 1996). Nevertheless, the recent shift towards a marketbased economy appears to have introduced capitalist business practices (HassabElnaby and 
Mosebach, 2005). This paper takes the view that there is no apparent reason to believe that Egyptian managers have different personal wealth-related motivations to those of their counterparts in Western capitalist countries. Hence one would expect that the relationships between bonus schemes (where they exist) and accounting choices that have been observed in other capitalist economies will also be observed in Egypt. Consequently, it is assumed here that the conventional PAT bonus plan hypothesis is relevant in Egypt. It is adapted in the current research to the alternative hypothesis (H1), below.

H1 Alternative: In Egypt, managers of firms with bonus plans are more likely to adopt current income-increasing accounting choices than those without bonus plans.

\section{Debt Contracts Hypothesis}

The literature about the association between levels of financial gearing and accounting policies (see, for example, Bowen et al., 2000) usually focuses on long-term debt (Duke and Hunt, 1990; Press and Weintrop, 1990; Sweeney, 1994). Violation of contractual debt covenants can impose significant costs on firms. Since current income increasing accounting methods can reduce the immediate constraints from some commonly observed covenants ${ }^{4}$, managers have incentives to use such methods when such constraints might be activated. An assumption that the likelihood of violating covenants is positively associated with gearing then leads to the conventional debt hypothesis that the level of gearing is positively associated with the extent to which managers choose income increasing accounting methods (Watts and Zimmerman, 1978; 1986). Other things being equal, an increase in accounting earnings will increase the book value of equity and consequently reduce the gearing ratio (DeFond and Jiambalvo, 1994; Sweeney, 1994). Much of the literature relates to the existence of contractual accounting based debt covenants. One can reasonably also claim, however, that the existence of relatively high levels of financial gearing is likely to either deter potential 
lenders or alternatively to lead them to impose more onerous conditions in any loan contract. Consequently, levels of financial gearing that are considered to be high, relative to other firms in the industry involved, can be expected to reduce further financing opportunities. Therefore, there are implicit institutional constraints on the acceptable level of leverage. Logically, the strength of managers' motivations reflected in the debt hypothesis depends on the costs of violating the firm's debt covenants (Holthausen and Leftwich, 1983) and on the likelihood that the gearing level will adversely affect future financing. The empirical evidence on the debt hypothesis remains largely mixed. DeFond and Jiambalvo (1994) and Sweeney (1994) reported results which were consistent with it, but Healy and Palepu (1990) and DeAngelo et al. (1994) documented an inconsistent set of results.

Most prior research has examined large Western corporations that issue long-term bonds and have an extensive equity base. In contrast, banks are the main source of borrowing by Egyptian industry; sometimes banks also own a percentage of the share capital (PCSU, 2000). Relationships and contracts with Egyptian lenders could therefore be significantly different to those in Western capitalist economies. Given this situation, the debt covenant hypothesis might not offer the same explanatory power for the accounting choices of Egyptian companies. HassabElnaby and Mosebach (2005) identified that accounting-based debt covenants (ABDCs) are used less frequently in Egypt than in the USA. Nevertheless, many Egyptian corporations rely heavily on debt, and HassabElnaby and Mosebach did observe an increasing trend towards the use of ABDCs in Egypt. They also noted that gearing ratios were the most frequently used $\mathrm{ABDC}$. There seems to be no reason why the above mentioned implicit gearing related constraints on borrowing should not apply in Egypt. Consequently, despite the lower level of contractual constraints, the conventional debt covenant hypothesis is assumed to be relevant to Egypt despite the different contracting environment. Therefore, this paper adopts that hypothesis, treating gearing as the independent 
variable and current income increasing accounting methods as the dependent variables. $\mathrm{H} 2$ is the resulting hypothesis.

H2 (Alternative): In Egyptian firms, the use of current income-increasing accounting choices is positively associated with leverage.

Some taxation regimes make stipulated adjustments to accounting income when computing taxable income. A particularly important adjustment in many countries, which is also made in Egypt, relates to depreciation. Accounting depreciation is disallowed for tax purposes and is replaced by depreciation allowances that are calculated using methods and rates that are stipulated by the government agencies involved. In contrast, inventory valuations in the income statements are accepted without adjustments for taxation purposes, provided that they comply with acceptable accounting standards. The consequences are that enhancements to accounting income arising from policy choices affecting depreciation do not incur an extra tax charge, whereas those arising from inventory valuations do incur a charge.

Appendix 1 models the differences that arise from the different situations ${ }^{5}$. It demonstrates that: (a) managers will always receive less bonus (based on after tax profits) from increases in accounting income that are subject to tax than those that are not subject to tax (the difference could be large with high rates of tax); (b) that the reduction in the firm's cash flows is higher with taxable enhancements than with non-taxable enhancements with any positive rate of taxation and bonus rates of less than $100 \%$ of the income enhancement; and (c) that rejection of income enhancing accounting adjustments will usually lead to higher future bonuses when the resulting enhancements are taxable than when they are not taxable. Consequently, managers with bonus plans, based on after-tax earnings, will gain more personal wealth from accounting policies that increase income without effect on tax charges than from policies which result in increases in current tax charges. The reasoning and 
evidence that underpin the adoption of the debt hypothesis (H2) suggests that bonus schemes may not be the only motivation for increasing earnings. Clearly, when managers increase taxable profit in order to achieve other benefits, such as enhanced borrowing capacity, current taxation costs will usually also increase. Consequently, there is a clear advantage to managers who wish to increase reported earnings to make policy decisions that do not affect tax charges (see, for example, Fields et al., 2001 for a discussion concerning the choice of accounting policies that reduce tax charges). This leads to an expectation that rational managers would prefer to make accounting income increasing adjustments that do not affect tax charges to those that affect such charges.

Accepting these arguments leads to the following hypothesis:

H3 (Alternative): In Egyptian firms, managers with bonus schemes are more likely to adopt current income increasing accounting methods that do not affect taxation charges than methods that increase taxation charges.

\section{EMPIRICAL HYPOTHESES}

The hypotheses $\mathrm{H} 1$ and $\mathrm{H} 2$ identify the dependent variable 'current income-increasing accounting choice' and independent variables 'management bonus scheme' and 'leverage'. In order to test them one needs to identify empirically observable data that can proxy for such variables. In the past, accounting choices whose effect on current net income is relatively unambiguous and which are usually disclosed in the corporation's annual report have been used as proxies for current income increasing policies (see, for example, Hagerman and Zmijewski, 1979; Zmijewski and Hagerman, 1981; Healy, 1985; DeAngelo, 1988). This paper follows a similar strategy.

The dependent variables most widely used in the literature to indicate income increasing accounting methods are depreciation method, inventory method, the treatment of investment tax credits and the period of pension amortisation (see, for example, Hagerman 
and Zmijewski, 1979; Holthausen and Leftwich, 1983; Watts and Zimmerman, 1986; Penno and Simon, 1986; Dhaliwal, 1988; Press and Weintrop, 1990; Bowen et al., 2000; Bowen et al., 2002). Investment tax credits operate in the USA and some Western countries but not in Egypt. Also, pension amortisation does not appear in the Egyptian income statements, because under Egyptian Accounting Standard (EAS) No. 21 the pension system is subject to a special fund system and the investment of this special fund has a separate financial statement.

This study therefore only examines depreciation method (using the subscript ' a') and inventory valuation choices (using ' b'), which arguably are sufficient because they can have large and systematic effects on the assets and expenses reported in firms' financial statements (Bowen et al., 2000; 2002). The literature usually assumes that the adoption of (a) straightline depreciation (SLD) and (b) the first-in-first-out (FIFO) stock valuation method will increase reported earnings in the short-term. FIFO will only consistently increase current earnings if replacement costs of inventory usually rise over time, which has occurred in Egypt, where average annual inflation ranged between $2.8 \%$ and $9.4 \%$ during the period 1994 to 2001. The conventional assumptions are therefore relevant to, and are adopted in, this study. They lead to two sets of empirically testable sub-hypotheses, $H_{a}$ refers to depreciation and $\mathrm{H}_{\mathrm{b}}$ to inventory valuation.

As indicated above, the commonly identified economic factors that might influence a firm's choice of accounting methods are in this paper hypothesised to be the existence of a management bonus scheme and a firm's gearing characteristics (see $\mathrm{H} 1$ and $\mathrm{H} 2$ ). Healy (1985) has shown that the contractual details of specific bonus plans can have a significant effect on managers' accounting choices. Such details are not publicly available in Egypt. Consequently, when testing H1, the bonus variable (MP) was measured as one (1) if the managers have bonus plans based on accounting numbers and zero (0) if not. $\mathrm{H} 2$ was tested using firms' total debt to total assets as the independent variables. Both that variable and the 
long-term debt to equity ratio have been widely employed in the literature as proxies for a firms' dependency on debt financing (Duke and Hunt, 1990; Press and Weintrop, 1990; Healy and Palepu, 1990; DeAngelo et al., 1994; Jung and Kwon, 2002; Bauwhede et al., 2003). HassabElnaby and Mosebach (2005) observed that in Egypt the most widely used constraint was 'tangible net worth'. Nevertheless, the total debt to total assets ratio was chosen in this study because the alternatives were not identifiable from the survey data. Although the ratio of debt to tangible net worth was available for database firms, the debt to total assets ratio was also used for those firms, in order to enhance comparability of the findings concerning the two data sets. The likelihood of observing significant relationships will be reduced if total assets is an inferior basis compared to net assets. Consequently, any such relationships, if found, are likely to be acceptable evidence. The same reasoning would also apply if gearing is considered to be inferior to interest coverage as a representation of potential debt-related constraints, which is perhaps unlikely in Egypt given HassabElnaby and Mosebach's observations.

Adoption of the proxy variables identified above enables the hypotheses $\mathrm{H} 1$ and $\mathrm{H} 2$ to be reformulated by replacing the terms 'current income increasing accounting choices' by (a) straight-line depreciation (SLD) and (b) first-in first-out (FIFO) stock valuation for each test. Table 1 shows the resulting hypothesised associations for $\mathrm{H} 1$ and $\mathrm{H} 2$.

\section{TABLE 1 ABOUT HERE}

As indicated above, in Egypt reductions in depreciation figures in the financial statements do not give rise to increases in taxation charges. In contrast, increases in the value of inventory will increase taxation charges (Abdel-Rahman, 2001). Therefore the empirical alternative hypothesis for $\mathrm{H} 3$ can be formulated as: 
H3 (Alternative): In Egyptian firms, managers are more likely to use SLD than FIFO methods.

Table 2 summarises the variables used in the study and the basis on which they were measured. A measure of size is included as a control variable ${ }^{6}$, because such measures have been found to influence the findings of other relevant empirical studies. In their review of 14 papers from the empirical research literature on accounting choice, Holthausen and Leftwich (1983) found that firm size and gearing were the only two significant variables explaining choices of accounting techniques (see also Fields et al., 2001).

TABLE 2 ABOUT HERE

\section{RESEARCH METHOD AND DATA}

Accounting policies, the use of management bonus plans and gearing were obtained from databases $^{7}$ of companies listed on the Cairo Stock Exchange. Most empirical studies of accounting choice tend to rely on such sources, but in this case the available data was limited to companies that were actively traded ${ }^{8}$. Consequently, the resulting database sample of 96 companies $^{9}$ was biased towards businesses that were larger and more widely held than most Egyptian firms. It was thought that information about smaller firms and those with more concentrated ownership would enhance the study; a questionnaire was therefore distributed to the 320 largest (by working capital in 2001) firms ${ }^{10}$ operating in the Cairo, Alexandria and Menoufia Governorates, which are the most industrialised areas in Egypt. Ninety-three firms responded to the questionnaire, a response rate of $29 \%$. The sizes of the firms in the database and the survey are shown in Table 3, using both total sales and total assets ${ }^{11}$. The mean of SALES categories ( 1 to 8 ) is 3.9 for the survey companies and 5.4 for the database firms, so on average firms included in the database have larger sales than their counterparts included in the survey. Similarly, for total assets the mean categories are 3.0 for the survey firms and 4.58 
for the database firms. Table 3 shows that the range of values for both assets and sales in each category are unequal. This arose because the ranges appearing in the questionnaire were set in Egypt by the researcher administering the instrument, on the advice of local experts. The figures are, however, approximately on logarithmic scales. In order to enhance comparability with the survey results, the database firms were then analyzed using the same categories as applied to the survey firms - but with an extension of the categories because of the greater range of values involved.

\section{TABLE 3 ABOUT HERE}

Clearly, the companies in the database were on average much larger than those in the survey. There may have been a small overlap between the respondents in the survey and the firms identified in the database ${ }^{12}$, because more than half of the respondent firms in the questionnaire survey are listed on the stock exchange. Nevertheless, most of the latter are likely to be infrequently traded firms not included in the database. For the purposes of statistical analysis, the two samples were kept separate and the same tests were applied independently to both samples.

Table 4 shows information concerning the adoption of bonus schemes. Such schemes are clearly used to motivate agent-managers. They are unnecessary for controlling ownermanagers, who are able to determine for themselves the amount of cash withdrawn from the business for personal use. This paper therefore assumes that the existence or absence of bonus schemes indicates the ownership-control status of the firm. Comparison of survey and database firms in table 4 then suggests that far more of the database firms were agent managed firms than was the case with the survey firms.

\section{TABLE 4 ABOUT HERE}

The hypotheses $\mathrm{H} 1$ and $\mathrm{H} 2$ are tested by examining the association between the use of SLD and FIFO and (i) the existence of bonus schemes and (ii) the level of leverage. H3 is tested by 
examining the association between the choice of SLD and that of FIFO. The null hypotheses are all direct negatives of the alternative hypotheses.

The data used in the analysis was obtained from the survey and from the database, and not from a designed experiment. Consequently, the distribution of firms and managers with various characteristics arises by chance and may not allow straightforward comparisons of the effects as orthogonal contrasts. At least the usual level of multi-collinearity can be expected to be encountered in the data sets constructed. The existence of relationships between possible explanatory variables creates difficulties in ascribing different outcomes as being attributable to different levels of those variables. Given that situation, it is conventional practice to employ both simple and multivariate analysis to provide additional evidence in support of the multivariate findings. This paper adopts such a procedure in testing hypotheses $\mathrm{H} 1$ and $\mathrm{H} 2$ (see, for example Dechow et al., 1996).

\section{RESULTS}

\section{Descriptive Statistics}

Panel A of Table 5 presents the descriptive statistics for firms in the survey while Panel B does likewise for the database. Table 5 shows that, on average, firms included in the database have higher debt-to-total asset ratios than firms included in the survey, (with a mean of 3.5 compared with 2.4). They also make greater use of bonus schemes (mean 0.72) than firms in the survey (mean 0.54) implying that more of the survey firms are owner-managed.

\section{TABLE 5 ABOUT HERE}

\section{Univariate Analysis}

As indicated above, hypotheses $\mathrm{H} 1$ and $\mathrm{H} 2$ were tested separately from data recorded from the database and survey using univariate analysis ${ }^{13}$ and multivariate analysis (see, for example, Dechow et al., 1996). The results of the univariate analysis for $\mathrm{H} 1$ and $\mathrm{H} 2$ are set 
out in detail in Appendix 2 and summarised in Table 6. This indicates for H1 that MP, which is a proxy for management incentive plans, is significantly positively associated (at the $1 \%$ level) with management's choice of income-increasing methods (depreciation and inventory). This finding is consistent across both the questionnaire survey and the database firms so the null for $\mathrm{H} 1$ can be rejected. That observation is consistent with the prediction that managers with bonus plans are more likely to adopt income-increasing accounting choices than those without such bonus-based incentives $\left(\mathrm{H}_{\mathrm{a}}\right.$ and $\left.\mathrm{H} 1_{\mathrm{b}}\right)$.

\section{TABLE 6 ABOUT HERE}

The results for the gearing hypothesis $\mathrm{H} 2$ indicate that $L E V$, which is used as a proxy for the existence and tightness of a firm's debt covenants, is positively and significantly associated (at the 5\% level) with management's choice of income increasing depreciation methods in the database. Yet the association is not significant in the questionnaire survey. This could reflect the much lower average level of gearing (relative to the database) shown in Table 5. Although the coefficient of the associations between $L E V$ and management's choice of FIFO are positive, the associations are not statistically significant in either the questionnaire survey or the database. The null hypothesis $\mathrm{H} 2_{\mathrm{a}}$ can be rejected for the database, but the nulls for $\mathrm{H} 2_{\mathrm{b}}$ and $\mathrm{H} 2_{\mathrm{a}}$ for the survey cannot be rejected. Overall, the univariate results provide some support for the hypothesis that the higher the leverage, the greater the likelihood that a firm will choose the income increasing depreciation methods $\left(\mathrm{H} 2_{\mathrm{a}}\right)$. They provide no significant support for the prediction that the higher the leverage, the greater the likelihood that a firm will choose the inventory valuation method which increases current income $\left(\mathrm{H} 2_{\mathrm{b}}\right)$. As indicated above, depreciation charges are not used in taxation computations in Egypt, so increases in accounting earnings via reduced depreciation do not give rise to extra tax charges. The situation is different for inventory valuation - so one would expect executives to prefer adjustments made through depreciation to those made through a 
change in the inventory method.

Table 7 shows the number of firms with bonus schemes that use SLD and FIFO. It is interesting to observe that, by comparison with the database sample, survey firms were much more likely to use FIFO, an income increasing method given the inflationary environment in Egypt. The reasons for this are unclear. There is clearly a much greater propensity for firms in both samples to use SLD than FIFO. This finding was tested using chi-squared analysis and the resultant $\mathrm{p}$-value for $\mathrm{H} 3$ shown in Table 6 is statistically significant (at the $1 \%$ level). Therefore the null hypothesis can be rejected and the evidence is consistent with the validity of $\mathrm{H} 3$.

\section{INSERT TABLE 7 ABOUT HERE}

In summary, the univariate analyses results provide strong support for the bonus plans hypothesis $\left(\mathrm{H}_{\mathrm{a}}\right.$ and $\left.\mathrm{H}_{\mathrm{b}}\right)$. In addition, the results for the database are consistent with hypotheses $\mathrm{H} 2{ }_{\mathrm{a}}$ concerning the association between gearing and depreciation method, but there was no significant support for the hypothesis concerning depreciation from the survey. The hypothesis concerning the association between gearing and inventory valuation method $\left(\mathrm{H} 2_{b}\right)$ received no statistically significant support. The evidence provides strong support for the rejection of the null for $\mathrm{H} 3$. Overall, there appears to be a marked difference between accounting income accelerating behaviour relating to depreciation and to inventory - which could be attributable to their different treatment for taxation purposes.

One can reasonably claim that the univariate analysis provides evidence that the use of management incentive plans was positively and significantly related to the use of income increasing accounting choices, whether these choices related to depreciation or to inventory valuation methods. In the database, the level of gearing was significantly related to current income increasing depreciation accounting choices - although not to inventory decisions, which potentially affect charges for taxation. The analysis provides highly significant 
evidence consistent with the hypothesis that taxation factors influence the relative preferences for accounting income increasing methods. The observations concerning bonuses and gearing are consistent with many of the findings of earlier studies using univariate analysis (Fields et al., 2001). In the next section, a multivariate analysis provides the possibility of different insights concerning the relative influences of explanatory variables.

\section{Multivariate Analysis}

The multivariate analysis was performed for the survey sample with the variables listed in Table 2. It was undertaken for the database sample using all of the variables in Tables 2 and $8^{14}$. Appendix 3 contains more information about the variables used. As Appendix 4 explains, use of this range of variables produced an unacceptable level of multi-collinearity. Standard statistical techniques were therefore used to identify the variables that provided the most significant models, which were then checked for plausibility.

\section{INSERT TABLE 8 ABOUT HERE}

The identified variables were then used in the following logit model for each of the depreciation (DEP) and inventory (INV) valuation dependent variables. Consistent with the extant literature, $\beta_{1}$ and $\beta_{2}$ are predicted to be positive whereas $\beta_{3}$ is predicted to be negative, i.e.:

$\mathrm{DEP}($ or INV $)=\beta_{0}+\beta_{1} M P_{i}+\beta_{2} L E V_{i}+\beta_{3} \operatorname{SALES}_{i}$
Predicted signs
$(+)$
$(+)$
$(-)$

Statistically significant results for the multivariate analysis are shown in Appendix 5 and summarised in Table 9. The nulls for the set of $\mathrm{H} 1$ hypotheses are all rejected at highly significant levels. The results in that table show highly significant evidence consistent with 
the research hypotheses $\mathrm{H}_{1}$; firms that employ bonus plans seem more likely to opt for the SLD method than those without bonus plans (for the total survey and database samples). The survey and database samples also show strong evidence consistent with for the bonus hypotheses $\left(\mathrm{H}_{\mathrm{b}}\right)$, when tested by reference to the use of FIFO. Results for the gearing hypothesis $\mathrm{H} 2$ are mixed. The samples show significant rejection of the null $\mathrm{H} 2_{\mathrm{a}}$ (depreciation) for the database (at the 5\% level) but not for the survey. The null is not rejected in either sample for inventory decisions. Interestingly, the multivariate analysis in Table 9 shows exactly the same pattern of rejection of null hypotheses as the univariate analysis in Table 6. As indicated above, this observation provides an increased level of confidence that the observations reflect the characteristics of the samples.

\section{TABLE 9 ABOUT HERE}

\section{DISCUSSION}

The findings from the study as a whole (including both univariate and multivariate analyses) suggest that the existence of management incentive plans are significantly positively associated with depreciation policies and inventory valuation methods that increase accounting income. Also, there is some evidence that the gearing of database companies is positively associated with the choice of straight-line depreciation. One can conclude that the study provides statistically strong evidence consistent with the relevance of the bonus PAT hypothesis to accounting in Egypt, and some limited evidence consistent with the debt contracts hypothesis. It provides strong evidence consistent with the hypothesis that managers will prefer adjustments that do not increase tax payments to those that do increase such outlays.

It is perhaps not surprising that much of PAT, which is primarily based on the AngloAmerican experience and institutional environment, seems to be relevant to Egypt. Whilst this 
paper has not directly explored the question, one may reason that managers' motivations may to some extent be conditioned by the institutional, cultural, ethical and political environments in which they work. The findings of this study are consistent with recent research (HassabElnaby and Mosebach, 2005) which found an association between economic reform, socio-economic change, and accounting choice. In the climate of rapid institutional transformation to a market-driven economy, it could be expected that Egyptian managers will be influenced by 'rational' considerations of their personal wellbeing. The findings of this study suggest that motivations of managers in emerging capitalist economies may be influenced by similar factors to those that influence managerial behaviour in established capitalist economies.

This study inevitably suffers from the limitations of the data on which it is based. In particular, one should emphasise that consistency with hypotheses is not 'proof' that the hypotheses are 'correct'. There may be other reasons for accounting choices that are not identified in the study. The survey used in this analysis also sought data on respondents' opinions of the reasons for the choice of depreciation and of stock valuation methods. Analysis of that data will be presented in a subsequent study. 


\section{References}

Abd-Elsalam, O. and Weetman, P. 2003. Introducing International Accounting Standards to and Emerging Capital Market: Relative Familiarity and Language Effect in Egypt. Journal of International Accounting, Auditing and Taxation, 12: 63-84.

Abdel-Khalik, A. R. 1985. The Effect of LIFO-Switching and Firm Ownership on Executives Pay. Journal of Accounting Research, 23 (Autumn): 427-447.

Abdel-Rahman, A.M. 2001. Comparative Study on Corporate Tax: Prospects for Harmonization in the ESCWA Region. New York: United Nations Economic and Social Commission for Western Asia.

Aitken, M. J. and Loftus, J. A. 1994. Determinants of Accounting Policy Choice in the Australian Property Industry: A Portfolio Approach. Accounting and Finance, 34 (November): 1-20.

Amihud, Y., Kamin, J. Y. and Ronen, J. 1983. 'Managerialism', 'Ownerism' and Risk. Journal of Banking and Finance, 7 (June): 189-196.

Antle, R. and Smith, A. 1985. Measuring Executive Compensation: Methods and Applications. Journal of Accounting Research, 23 (Spring): 296-325.

Ball, R. J. and Foster, G. 1982. Corporate Financial Reporting: A Methodological Review of Empirical Research. Journal of Accounting Research, 20 (Supplement): 161-234.

Bauwhede, H. V., Willekens, M. and Gaeremynck, A. 2003. Audit Firm Size, Public Ownership, and Firms' Discretionary Accruals management. International Journal of Accounting, 38, 1-22.

Bowen, R. M., DuCharme, L. and Shores, D. 2000. Economic and Industry Determinants of Accounting Method Choice. Working Paper, University of Washington Business School, online: (http://papers.ssrn.com/sol3/delivery.cfm/991011205.pdf?abstractid=182888)

(18.1.2001).

Bowen, R., Rajgopal, S. and Venkatachalam, M. 2002. Accounting Choice, Corporate Governance and Firm Performance. Online:

http://faculty.fuqua.duke.edu/areas/accounting/documents $\% 20$ for $\% 20$ website/bowen $\% 20 \mathrm{rajg}$ opal\%20and\%20venkatachalam.pdf. (15.3.2003).

Brown, A.D. and Humphreys, M. 1995. International Cultural Differences in Public Sector Management: Lessons from a Survey of British and Egyptian Technical Education Managers. International Journal of Public Sector Management, 8(3): 5-23. 
Carlson, S. J. and Bathala, C. T. 1997. Ownership Differences and Firms' Income Smoothing Behavior. Journal of Business Finance and Accounting, 24 (March): 179-196.

Cloyd, B. C., Pratt, J. and Stock, T. 1996. The Use of Financial Accounting Choice to Support Aggressive Tax Positions: Public and Private Firms. Journal of Accounting Research, 34:1, 23-43.

Cushing, B. E. and LeClere, M. J. 1992. Evidence on the Determinants of Inventory Accounting Policy Choice. The Accounting Review, 67 (April): 355-366.

Daley, L. and Vigeland, R. 1983. The Effects of Debt Covenants and Political Costs on the Choice of Accounting Method: the Case of Accounting for R\&D Costs. Journal of Accounting and Economics, 5 (December): 195-211.

DeAngelo, H., DeAngelo, L. and Skinner, D. J. 1994. Accounting Choice in Troubled Companies. Journal of Accounting and Economics, 17: 113-143.

DeAngelo, L. E. 1986. Accounting Numbers as Market Valuation Substitutes: a Study of Management Buyouts of Public Stockholders. Accounting Review, 61 (July): 400-420.

Dechow, P. 1994. Accounting Earnings and Cash Flows as Measures of Firm Performance: The role of accounting accruals. Journal of Accounting and Economics, 18, 3-43.

Dechow, P., Hutton, A. and Sloan, R. 1996. Economic Consequences of Accounting for Stock-Based Compensation. Journal of Accounting Research, 34 (Supplement): 1-20.

DeFond, M. L. and Jiambalvo, J. 1994. Debt Covenant Violation and Manipulation of Accruals. Journal of Accounting and Economics, 17: 145-176.

Dempsey, S. J., Hunt, H. G. and Schroder, N. 1993. Earnings Management and Corporate Ownership Structure: An examination of extraordinary item reporting. Journal of Business Finance and Accounting, 20: 479-500.

Dhaliwal, D. S., Salamon G. L. and Smith E. D. 1982. The Effect of Owner Versus Management Control on the Choice of Accounting Methods. Journal of Accounting and Economics, 4:1, 41-53.

Dhaliwal, D. S. 1988. The Effect of the Firm's Business Risk on the Choice of Accounting Methods. Journal of Business Finance and Accounting, 15 (Summer): 289-302.

Doupnik, T. and Salter, S. 1995. External Environment and Accounting Practice: A Preliminary Test of a General Model of International Accounting Development. International Journal of Accounting, Education and Research, 30(2): 189-207.

Duke, J. and Hunt, H. 1990. An Empirical Examination of Debt Covenant Restrictions and Accounting-Related Debt Proxies. Journal of Accounting and Economics, 12:1-2, 45-63. 
El-Gazzar, S., Lilien, S. and Pastena, V. 1986. Accounting for Leases by Lessees. Journal of Accounting and Economics, 8 (October): 217-237.

Emanuel, D., Wong, J. and Wong, N. 2003 Efficient Contracting and Accounting. Accounting and Finance, 43, 149-166.

Fields, T., Lys, T. and Vincent, L. 2001. Empirical Research on Accounting Choice. Journal of Accounting and Economics, 31, 255-307.

Gadhoum, Y. and Zeghal, D. 2000. Demystifying the Illusion of the Positive Effects of Ownership Concentration on Corporate Performance. Working paper, CGA, Accounting Research Centre, online: http://www.unites.uqam.ca/esgcrg/papers/2000/10-2000.pdf

Gaver, J., Gaver, K. and Austin, J. 1995. Additional Evidence on Bonus Plans and Income Management. Journal of Accounting and Economics, 19, 3-28.

Gray, S., Campbell, L. and Shaw, J. 1984. International Financial Reporting: A Comparative International Survey of Accounting Requirements and Practice in 30 Countries. London: Macmillan.

Guidry, F., Leone, A. J. and Rock, S. 1999. Earnings-Based Bonus Plants and Earnings Management by Business-Unit Managers. Journal of Accounting and Economics, 26, 113 142.

Hagerman, R. L. and Zmijewski, M. 1979. Some Economic Determinants of Accounting Policy Choice. Journal of Accounting and Economics, 1 (August): 141-161.

Hall, B. 2002. Incentive Strategy II: Executive Compensation and Ownership Structure. Harvard Business School, Case No. 9-902-134.

HassabElnaby, H. and Mosebach, M. 2005. Culture's Consequences in Controlling Agency Costs: Egyptian Evidence. Journal of International Accounting, Auditing and Taxation, 14: 19-32.

Healy, P. M. 1985. The Effect of Bonus Schemes on Accounting Decisions. Journal of Accounting and Economics, 7: 85-107.

Healy, P. and Palepu, K. 1990. Effectiveness of Accounting-Based Dividend Covenants. Journal of Accounting and Economics, 12: 97-123.

Hindley, B. 1970. Separation of Ownership and Control in the Modern Corporation. Journal of Law and Economics, 13: 185-221.

Holthausen, R. W. and Leftwich W. R. 1983. The Economic Consequences of Accounting Choice: Implications of Costly Contracting and Monitoring. Journal of Accounting and Economics, 5, (August): 77-117. 
Holthausen, R., Larcker, D. and Sloan, R. 1995. Annual Bonus Schemes and the Manipulation of Earnings. Journal of Accounting and Economics, 19: 29-74.

Humphreys, M. 1996. Culture Difference and its Effect on the Management of Technical Education. Leadership and Organization Development Journal, 17 (2): 34-41.

Hunt, H. G. 1986. The Separation of Corporate Ownership and Control: Theory, Evidence and Implications. Journal of Accounting Literature, 5: 85-124.

Ittner, C. D., Larcker, D. F. and Rajan, M. V. 1997. The Choice of Performance Measures in Annual Bonus Contracts. Accounting Review, 72 (April): 231-255.

Jensen, M. C. and Meckling, H. W. 1976. Theory of the Firm: Managerial Behavior, Agency Costs and Ownership Structure. Journal of Financial Economics, 3: 305-360.

Jensen. M. C. and Murphy, K. 1990،“\#Performance Pay and Top Management Incentives. Journal of Political Economy, 98: 225-264.

Jung, K. and Kwon, S. Y. 2002. Ownership Structure and Earnings Informativeness Evidence from Korea. International Journal of Accounting, 37: 301-325.

Kim, W. S. and Sorenson, E. H. 1986. Evidence on the Impact of the Agency Costs of Debt on Corporate Debt Policy. Journal of Financial and Quantitative Analysis, 21: 131-144.

Lambert, R. and Larcker, D. 1987. An Analysis of the Use of Accounting and Market Measures of Performance in Executive Compensation Contracts. Journal of Accounting Research, 25 (Supplement): 85-129.

Lee, C. J. and Hsieh, D. A. 1985. Choice of Inventory Accounting Methods: Comparative Analyses of Alternative Hypotheses. Journal of Accounting Research, 23 (Autumn): 99-110.

Mikhail, M. 1999. Coordination of Earnings, Regulatory Capital and Taxes in Private and Public Companies. Working paper, MIT, Cambridge, MA, online: http://papers.ssrn.com/sol3/delivery.cfm/99051814.pdf?abstractid=165010 (4.7.2001).

Nachmias, D. and Nachmias, C. 1976. Research Methods in the Social Sciences, London: Edward Arnold.

Niehaus, G. R. 1989. Ownership Structure and Inventory Method Choices. Accounting Review, 64:2, 269-284.

PCSU (Privatization Coordination Support Unit) 2000. The Corporate Governance Policy Framework in Egypt Special Study, online: http://www.carana.com/pcsu/studies/Final.pdf, (8.11.2001). 
Pacecca, T. 1995. An Analysis of Submissions to the ASRB on Release 411 'Foreign Currency Translation. Accounting and Finance, 35 (November): 98-116.

Penno, M. and Simon, D. T. 1986. Accounting Choices: Public Versus Private Firms. Journal of Business Finance and Accounting, 13 (Winter): 561-568.

Press, E. and Weintrop, J. 1990. Accounting-Based Constraints in Public and Private Debt Agreements: Their Association with Gearing and Impact on Accounting Choice. Journal of Accounting and Economics, 12 (January): 65-95.

Short, M. 1994. Ownership, Control, Financial Structure and the Performance of Firms. Journal of Economic Surveys, 8:3, 203-249.

Sloan, R. G. 1993. Accounting Earnings and Top Executive Compensation. Journal of Accounting and Economics, 16, 55-100.

Smith, C. and Watts, R. 1982. Incentive and tax effects of executive compensation plans. Australian Journal of Management, 7 (December): 139-157.

Sweeney, A. P. 1994. Debt-Covenant Violations and Managers Accounting Responses. Journal of Accounting and Economics, 17: 281-308.

Smith, F. D. 1976. The Effect of the Separation of Ownership from Control on Accounting Policy Decision. Accounting Review, 51 (October): 707-723.

Stano, M. 1976. Monopoly Power, Ownership Control, and Corporate Performance. Bell Journal of Economics, 7 (Autumn): 672-679.

Warfield, T. D., Wild, J. J. and Wild, K. L. 1995. Managerial Ownership, Accounting Choices, and Informativeness of Earnings. Journal of Accounting and Economics, 20: 61-91.

Watts, R. L. and Zimmerman, J. L. 1978. Towards Positive Theory of the Determination of Accounting Standards. Accounting Review, 53: 112-134.

Watts, R. L. and Zimmerman, J. L. 1986. Positive Accounting Theory, Englewood Cliffs, NJ: Prentice-Hall.

Watts, R. L. and Zimmerman, J. L. 1990. Positive Accounting Theory: A Ten Year Perspective. Accounting Review, 65: 131-156.

Whittred, G. and Zimmer, I. 1992. Financial Accounting Incentives Effects and Economic Consequences, Sydney: Holt, Rinehart and Winston.

World Bank 2001. Corporate Governance Country Assessment: Arab Republic of Egypt. 
Zimmerman, J. L. 1983. Taxes and Firms Size. Journal of Accounting and Economics, 5: 119-149.

\section{Zmijewski, M. and Hagerman, R. 1981. An Income Strategy Approach to the Positive Theory of Accounting Standard Setting Choice. Journal of Accounting and Economics, 3: 129-149.}

\section{Notes}

${ }^{1}$ Other studies document a significant statistical association between variants of accounting earnings and incentive-pay programmes (see, for example, Antle and Smith, 1985; Lambert and Larcker, 1987; Jensen and Murphy, 1990).

${ }^{2}$ Hall (2002) noted that the use of stock options had increased substantially between 1990 and 1999 in the USA, but earnings-based bonuses are the most common in Egypt.

${ }^{3}$ Most of these methods result in lower earnings in later years - for example, increased inventory values in the current period lead to increased costs in subsequent periods.

${ }^{4}$ Increases in accounting income increase both the ratios of earnings to interest and (subject to any resulting withdrawals of cash by way of bonuses or additional dividends) of net assets to debt, both of which feature in debt contracts (see, for example, Duke and Hunt, 1990; Healy and Palepu, 1990; Press and Weintrop, 1990).

5 This appendix proves what is perhaps intuitively obvious, but also shows analytically the interaction of variables in the differing situations.

${ }^{6}$ The selection of total sales as the specific proxy measure was motivated by (a) the wide range of industry sectors (both capital and labour intensive) included in the survey firms in the study and (b) the statistical limitations of using total assets data in the analysis (see note 11).

7 Data was compiled from three resources: (i) the Capital Market Authority in Cairo, (ii) the Disclosure Department of Cairo Stock Exchange and (iii) the Kompass Egypt business database. The resulting database did not include information concerning industry classifications.

${ }^{8}$ The Egyptian Stock Exchange identifies companies as either, (i) actively traded; or (ii) rarely traded. The rarely traded companies are in most cases closely held.

${ }^{9}$ Only firms for which (a) the complete financial statements were obtained for the years 1999-2001 and which (b) adopted and disclosed unchanged depreciation and inventory policies during the years ending 1999-2001 were included in the sample. The data used in the study is based on observations collected from the financial statements ending in 2001.

${ }^{10}$ It was felt that larger firms were more likely to exhibit the range of variables being investigated.

${ }^{11}$ Because the standard error of the coefficient of the variable for total assets was larger than it would have been with the absence of multicollinearity, this variable was not included as a control variable in the statistical analysis.

${ }^{12}$ Any direct comparison was prevented because of the anonymity of responses, adopted because it was judged that such a policy would increase the response rate. The distribution of questionnaires was not restricted to firms not included in the database, because it was intended to analyse each of the database and survey data sets independently and the authors felt that it was therefore preferable to send the survey to all firms in the identified category. Because of the independent analysis of each data set this has not resulted in double counting results.

${ }^{13}$ For the univariate statistical analysis the chi-squared test, using a 2 × 2 contingency table, was utilized to establish the association between the dependent variables and the dichotomous independent variable $M P$. The relationship between the dependent variables and the categorical independent variable $L E V$ was investigated using the non-parametric Kendall's tau-b test of association for ordinal variables.

${ }^{14}$ The data for all of the variables in Table 8 (with the exception of ASSETS) was not available for the survey sample. 
Table 1: Alternative Sub-hypotheses for $\mathrm{H1}$ and $\mathrm{H2}$

\begin{tabular}{lcc}
\hline Positive association with use of income-increasing methods & H1 (bonus plans) & H2 (leverage) \\
\hline Firms using SLD & $\mathbf{H} \mathbf{1}_{\mathrm{a}}$ & $\mathbf{H} \mathbf{2}_{\mathrm{a}}$ \\
Firms using FIFO & $\mathbf{H} \mathbf{1}_{\mathrm{b}}$ & $\mathbf{H} \mathbf{2}_{\mathrm{b}}$ \\
\hline
\end{tabular}

Table 2: Variable Definitions and Measurement

\begin{tabular}{|c|c|c|}
\hline Variable & Type of variable & Measurement method \\
\hline Depreciation method (DEP) & Dependent variable & $\begin{array}{l}\text { Coded } 1 \text { if the firm adopts SLD and } 0 \text { if the firm } \\
\text { adopts other methods of depreciation. }\end{array}$ \\
\hline $\begin{array}{l}\text { Inventory valuation method } \\
(I N V)\end{array}$ & Dependent variable & $\begin{array}{l}\text { Coded } 1 \text { if the firm adopts FIFO method of } \\
\text { inventory valuation and } 0 \text { if the firm chooses other } \\
\text { methods of inventory valuation. }\end{array}$ \\
\hline $\begin{array}{l}\text { Existence of Management } \\
\text { incentive plans }(M P)\end{array}$ & Independent variable & $\begin{array}{l}\text { Coded } 1 \text { if the managers have bonus plans based } \\
\text { on accounting figures and } 0 \text { if not. }\end{array}$ \\
\hline Gearing $(L E V)$ & Independent variable & $\begin{array}{l}\text { The ratio computed by the company's debt / total } \\
\text { assets, coded } 1-5 \text {. }\end{array}$ \\
\hline Firm Size $(S A L E S)$ & Control variable & $\begin{array}{l}\text { Measured by total sales, coded } 1-5 \text { in the survey } \\
\text { sample and } 1-8 \text { in the database sample. }\end{array}$ \\
\hline
\end{tabular}

Table 3: Categorisation by Total Assets and by Total Sales

\begin{tabular}{|c|c|c|c|c|c|c|c|c|}
\hline \multirow[b]{3}{*}{ Cat. } & \multicolumn{4}{|c|}{ Panel A: Total Assets } & \multicolumn{4}{|c|}{ Panel B: Total Sales } \\
\hline & \multicolumn{2}{|c|}{ Survey Firms } & \multicolumn{2}{|c|}{ Database Firms } & \multicolumn{2}{|c|}{ Survey firms } & \multicolumn{2}{|c|}{ Database firms } \\
\hline & $\begin{array}{r}\text { Assets (£m } \\
\text { Egyptian) }\end{array}$ & Total & $\begin{array}{r}\text { Assets (£m } \\
\text { Egyptian) }\end{array}$ & Total & $\begin{array}{l}\text { Sales (£m } \\
\text { Egyptian) }\end{array}$ & Total & $\begin{array}{l}\text { Sales (£m } \\
\text { Egyptian) }\end{array}$ & Total \\
\hline 1 & $<50$ & 10 & $<50$ & 1 & $<10$ & 8 & $<10$ & 2 \\
\hline 2 & $50-100$ & 27 & $50-100$ & 7 & $10-25$ & 11 & $10-25$ & 2 \\
\hline 3 & $100-250$ & 24 & $100-250$ & 23 & $25-50$ & 10 & $25-50$ & 3 \\
\hline 4 & $250-500$ & 16 & $250-500$ & 17 & $50-100$ & 18 & $50-100$ & 18 \\
\hline 5 & $500+$ & 16 & $500-1,000$ & 21 & $100+$ & 46 & $100-250$ & 25 \\
\hline 6 & & & $1,000-2,500$ & 13 & & & $250-500$ & 18 \\
\hline 7 & & & $2,500-5,000$ & 7 & & & $500-1,000$ & 15 \\
\hline 8 & & & $>5,000$ & 7 & & & $>1,000$ & 9 \\
\hline & TOTAL & 93 & TOTAL & 96 & TOTAL & 93 & TOTAL & 92 \\
\hline
\end{tabular}

Note: Complete sales data for four companies from the database sample could not be obtained. 
Table 4: Usage of Management Bonus Schemes

\begin{tabular}{lcc} 
& \multicolumn{3}{c}{ Panel A: Survey firms } \\
& Number of firms & $\%$ \\
\hline No bonus scheme & 43 & 46.2 \\
Bonus scheme & 50 & 53.8 \\
Total & 93 & 100.0 \\
\hline
\end{tabular}

Panel B: Database firms

Number of firms $\%$

No bonus scheme $\quad 27 \quad 28.1$

$\begin{array}{lll}\text { Bonus scheme } & 69 & 71.9\end{array}$

\begin{tabular}{lrr} 
Total & 96 & 100.0 \\
\hline
\end{tabular}

Table 5: Descriptive Statistics

\begin{tabular}{|c|c|c|c|c|c|}
\hline \multicolumn{6}{|c|}{ Panel A: Survey firms } \\
\hline Variable & Mean & Median & Std. Dev. & Min. & Max. \\
\hline$D E P$ & 0.796 & 1 & 0.405 & 0 & 1 \\
\hline$I N V$ & 0.430 & 0 & 0.498 & 0 & 1 \\
\hline$M P$ & 0.538 & 1 & 0.501 & 0 & 1 \\
\hline$L E V$ & 2.355 & 2 & 1.204 & 1 & 5 \\
\hline SALES & 3.892 & 4 & 1.363 & 1 & 5 \\
\hline \multicolumn{6}{|c|}{ Panel B: Database firms } \\
\hline Variable & Mean & Median & Std. Dev. & Min. & Max. \\
\hline$D E P$ & 0.885 & 1 & 0.320 & 0 & 1 \\
\hline$I N V$ & 0.198 & 0 & 0.401 & 0 & 1 \\
\hline$M P$ & 0.719 & 1 & 0.452 & 0 & 1 \\
\hline$L E V$ & 3.469 & 3 & 1.036 & 1 & 5 \\
\hline SALES & 5.402 & 5 & 1.569 & 1 & 8 \\
\hline
\end{tabular}

Note: See Table 2 for definitions of variables and for the scales and the bases on which they were measured.

Table 6: A Summary of Results of the Univariate Analysis

\begin{tabular}{|c|c|c|c|c|}
\hline & \multicolumn{2}{|c|}{ Depreciation } & \multicolumn{2}{|c|}{ Inventory } \\
\hline & Survey & Database & Survey & Database \\
\hline Null for $\mathrm{H} 1$ rejected & \multicolumn{2}{|c|}{ H1 $1_{a}$} & \multicolumn{2}{|c|}{$H 1_{b}$} \\
\hline \multirow{3}{*}{ Null for $\mathrm{H} 2$ rejected } & $\mathrm{p}=0.000^{* *}$ & $\mathrm{p}=0.000^{* *}$ & $\mathrm{p}=0.0005^{* *}$ & $\mathrm{p}=0.003^{* *}$ \\
\hline & & & \multicolumn{2}{|c|}{$\mathbf{H} \mathbf{2}_{\mathrm{b}}$} \\
\hline & $\mathrm{p}=0.209$ & $\mathrm{p}=0.019^{*}$ & $\mathrm{p}=0.301$ & $\mathrm{p}=0.711$ \\
\hline Null for $\mathrm{H} 3$ rejected for & \multirow{2}{*}{\multicolumn{4}{|c|}{$\begin{array}{c}\mathbf{H 3} \\
\mathrm{p}=0.000 * *\end{array}$}} \\
\hline both survey \& database & & & & \\
\hline
\end{tabular}


Table 7: Summary of Usage of SLD and FIFO by Sampled Firms with Bonus Schemes

\begin{tabular}{lcc}
\hline & Survey Firms & Database Firms \\
\hline Use SLD & 49 & 68 \\
Do not use SLD & 1 & 1 \\
Total & 50 & 69 \\
\hline Use FIFO & 29 & 18 \\
Do not use FIFO & 21 & 51 \\
Total & 50 & 69 \\
\hline
\end{tabular}

Table 8: Additional database sample variables definition and measurement Variable Type of variable Measurement method

Firm Size (ASSETS) Independent variable Measured by using total assets

Risk $\left(B E T A_{i}\right) \quad$ Control variable The firm-specific systematic risk measured by the company's beta estimated from the market model. Beta computed using the daily returns around December 31, 2000 and a value weighted market index. Beta was obtained from the CMA in Cairo.

Capital intensity $\left(C I_{i}\right) \quad$ Control variable The fixed assets divided by total sales

Competition $\left(C R_{i}\right) \quad$ Control variable Concentration ratios were measured by eight-firms concentration ratios for industries (percentage of sales).

PROFIT $_{i} \quad$ Control variable Measured as earnings before interest and taxes for the financial year divided by the book value of assets.

TAXRATE $_{i} \quad$ Control variable Tax expense divided by net income. 
Table 9: A Summary of Results for the Multivariate Analysis

\begin{tabular}{|c|c|c|c|c|}
\hline & \multicolumn{2}{|c|}{ Depreciation } & \multicolumn{2}{|c|}{ Inventory } \\
\hline & Survey & Database & Survey & Database \\
\hline \multirow[t]{2}{*}{ Null for $\mathrm{H} 1$ rejected } & \multicolumn{2}{|c|}{$H 1_{a}$} & \multicolumn{2}{|c|}{$H 1_{b}$} \\
\hline & $\mathrm{p}=0.0003^{* *}$ & $\mathrm{p}=0.0001 * *$ & $\mathrm{p}=0.001^{* *}$ & $\mathrm{p}=0.001 * *$ \\
\hline \multirow[t]{2}{*}{ Null for $\mathrm{H} 2$ rejected } & \multicolumn{2}{|c|}{$\mathrm{H} \mathbf{2}_{\mathrm{a}}$} & \multicolumn{2}{|c|}{$\mathbf{H} 2_{b}$} \\
\hline & $\mathrm{p}=0.105$ & $\mathrm{p}=0.033^{*}$ & $\mathrm{p}=0.158$ & $\mathrm{p}=0.165$ \\
\hline
\end{tabular}




\section{Appendix 1: Comparison of cash flows with taxable and non-taxable enhancements of}

\section{accounting income}

Bonus receipts

Assume that bonuses are paid as a percentage of after tax accounting income.

$E_{l}=$ the increase in income from an accounting adjustment that is not subject to taxation

$E_{2}=$ the increase in income from an accounting adjustment that is subject to taxation

$b=$ the proportion of accounting income increases that is paid in bonuses to managers

$t=$ the rate of tax paid on income

$B_{l}=$ the amount of bonus paid on $E_{l}$

$B_{2}=$ the amount of bonus paid on $E_{2}$

Assume that $E_{1}=E_{2}=E$

$$
\begin{aligned}
& B_{1}=b E \\
& B_{2}=b E(1-t) \\
& B_{1}-B_{2}=t b E
\end{aligned}
$$

The conclusion from this is that managers with bonuses based on after tax profits will always receive less bonus from enhancements subject to taxation than from those that are not - the reduction will be reflected by the rate of taxation.

\section{Firm's cash flows}

Now consider the differential effects of $E_{1}$ and $E_{2}$ on the firm's cash flows - ignoring lags in the payment of taxes. The latter merely complicates the illustration without adding additional insights.

Let $\quad C_{1}=$ cash outflows from $E_{1}$

$C_{2}=$ cash outflows from $E_{2}$ 
Then $C_{l}=b E$

$$
\begin{aligned}
& C_{2}=t E+b E(1-\mathrm{t}) \\
& =E(t+b-t b) \\
& C_{2}-C_{1}=t E(1-b)
\end{aligned}
$$

Hence, even after the reduction in bonus consequent on $E_{2}$ instead of $E_{1}$, the firm suffers the outflow of cash as a consequence of making adjustments that create tax charges instead of those that do not create such charges.

\section{Effects of current bonuses on future bonuses}

Assume that managers expect that they will remain in post for the next operating period and that their bonuses will remain at $b$ of accounting enhancements. Further, assume that they expect that investments $I$ made in the current period will yield $I(1+r)$ in period 2 . Then it will be worthwhile for managers to forgo bonus $b E_{1}$ if that sum is re-invested and

$$
p<i<r
$$

where $p=$ managers' time preferences consumption, $i=$ their opportunity cost of capital (i.e. the rate at which they can personally invest).

For then they would prefer to invest rather than to consume and

$$
b E_{l}(1+i)<b E_{l}(1+r)
$$

Hence, the bonus hypothesis implicitly assumes either that $p>r$, that $i>r$ or that the manager does not anticipate continuity of employment on the same terms.

Avoidance of $E_{2}$ provides proportionately more cash to invest $(\Delta I)$ than avoidance of $E_{1}-$ i.e. from [6]

$$
\Delta I=t E(1-b)
$$

leading to additional future bonuses (from [2]) 


$$
\Delta B_{2 F}=t E(1-b)(1+r)(1-t)
$$

With $r$ positive and $b$ and $t$ less than 1, equation 7 will always provide a positive value. Consequently, the reward to managers for deferring receipt of bonus will always be greater when the enhancement in income is taxable than when it is not taxable. Note that if bonuses are paid on the basis of pre-tax accounting income the term '- $t$ ' disappears from [7] - and the conclusion is unchanged. 


\section{Appendix 2: Univariate Statistical Analysis}

Table A1: Associations between Dependent Variables and Management bonus schemes

\begin{tabular}{|c|c|c|c|c|c|c|}
\hline \multicolumn{7}{|c|}{ Panel A: Association with Depreciation } \\
\hline \multirow[b]{2}{*}{ MP } & \multicolumn{3}{|c|}{ Survey firms } & \multicolumn{3}{|c|}{ Database firms } \\
\hline & No SLD & Uses SLD & Total & No SLD & Uses SLD & Total \\
\hline No bonus scheme & 18 & 25 & 43 & 10 & 17 & 27 \\
\hline Bonus scheme & 1 & 49 & 50 & 1 & 68 & 69 \\
\hline \multirow[t]{2}{*}{ Total } & 19 & 74 & 93 & 11 & 85 & 96 \\
\hline & \multicolumn{3}{|c|}{$\begin{array}{c}\text { Likelihood Ratio: } 25.903 \\
\text { p-value for a one-sided test: } 0.000\end{array}$} & \multicolumn{3}{|c|}{$\begin{array}{c}\text { Likelihood Ratio: } 22.303 \\
\text { p-value for a one-sided test: } 0.000\end{array}$} \\
\hline
\end{tabular}

Panel B: Association with Inventory

Survey firms

Database firms

\begin{tabular}{lcccccc}
\multicolumn{1}{c}{ MP } & No FIFO & FIFO & Total & No FIFO & FIFO & Total \\
\hline No bonus scheme & 32 & 11 & 43 & 26 & 1 & 27 \\
Bonus scheme & 21 & 29 & 50 & 51 & 18 & 69 \\
Total & 53 & 40 & 93 & 77 & 19 & 96
\end{tabular}

Likelihood Ratio: 10.171

Likelihood Ratio: 7.759

p-value for a one-sided test: 0.0005

p-value for a one- sided test: 0.003

Note: (a) this analysis is based on the Chi-squared test; (b) there is a positive association between the use of bonus schemes and the use of both SLD and FIFO.

Table A2: Associations between Dependent Variables and Leverage

\begin{tabular}{lcccccc}
\hline \multicolumn{5}{c}{} & \multicolumn{3}{c}{$\begin{array}{c}\text { Panel A: Association with Depreciation } \\
\text { Survey firms } \\
\text { LEV }\end{array}$} & No SLD & Uses SLD & Total & No SLD & Uses SLD & Total \\
\hline$<20 \%$ & 7 & 19 & 26 & 1 & 2 & 3 \\
$20-40 \%$ & 6 & 25 & 31 & 3 & 10 & 13 \\
$>40-60 \%$ & 2 & 18 & 20 & 5 & 28 & 33 \\
$>60-80 \%$ & 4 & 5 & 9 & 1 & 29 & 30 \\
$>80 \%$ & - & 7 & 7 & 1 & 16 & 17 \\
Total & 19 & 74 & 93 & 11 & 85 & 96 \\
& Kendall's tau-b: 0.078, DF: 4 & \multicolumn{2}{c}{ Kendall's tau-b: 0.207, DF:4 } \\
& p-value for a one- sided test: 0.209 & p-values for a one- sided test $=0.019$ \\
\hline
\end{tabular}

Panel B: Association with Inventory

Survey firms

Database firms

\begin{tabular}{lcccccc}
\multicolumn{1}{c}{ LEV } & No FIFO & FIFO & Total & No FIFO & FIFO & Total \\
\hline$<20 \%$ & 16 & 10 & 26 & 3 & - & 3 \\
$20-40 \%$ & 17 & 14 & 31 & 9 & 4 & 13 \\
$>40-60 \%$ & 11 & 9 & 20 & 27 & 6 & 33 \\
$>60-80 \%$ & 7 & 2 & 9 & 23 & 7 & 30 \\
$>80 \%$ & 2 & 5 & 7 & 15 & 2 & 17 \\
Total & 53 & 40 & 93 & 77 & 19 & 96 \\
\multicolumn{5}{r}{} & Kendall's tau-b: 0.049, DF: 4 & \multicolumn{2}{c}{ Kendall's tau-b: -0.050, DF: 4} \\
& p-values for a one- sided test: 0.301 & p-values for a one- sided test $=0.711$ \\
\hline
\end{tabular}

Note: Gearing is positively associated with both SLD and FIFO. 


\section{Appendix 3: Selection of Variables in Multi-variate Analysis}

In the questionnaire survey, size was measured using three measures: namely, current market value (SIZE1), the total value of sales $(S A L E S)$ and the balance sheet value of the total assets reported in the most recent financial statements (ASSETS). When determining the size measure to be employed in the current analysis for the responses to the questionnaire survey, market value (SIZE1) was eliminated because many respondents did not provide this information. Thus, in both the questionnaire survey and the database, size was initially measured using (a) the total value of sales (SALES) and (b) the most recently reported balance sheet figure for the total assets (ASSETS). For all companies in the database firms, the 'most recently reported balance sheet figure' related to the financial year ending in 2001. For the survey firms, the questionnaire specifically asked for the most recently reported figure.

\section{Control Variables}

The hypothesized relationship between dependent and explanatory variables is influenced by other factors that should be controlled in the analysis. Hagerman and Zmijewski (1979) argued that firms with (i) high systematic risk, (ii) high capital intensity technology or (iii) belonging to industries which have high concentration ratios have incentives to reduce the mean of their reported earnings through choosing income decreasing accounting choices. Their argument is based on the belief that high accounting profits by firms with these characteristics are more likely to compensate investors for the additional risk being borne and to avoid attracting new competitor entrants into the sector. A similar approach has been adopted in the current study. The three variables suggested by Hagerman and Zmijewski (1979) were initially employed as controls in the current study; in addition, another two variables (PROFIT and TAXRATE) were also included as control measures. 
The definition of risk in the current study is the beta coefficient from the market model which is calculated as the volatility of the company's share relative to the volatility of the market as a whole. BETA coefficients were available for the 96 firms included in the database from the CMA in Cairo. They were computed using the daily returns around December 31, 2000 and a value weighted market index. Relative capital intensity $(C I)$ was estimated by dividing fixed assets by total sales. As Hagerman and Zmijewski (1979) suggest, the concentration ratio (CR) is assumed to be a proxy variable for the ability of a firm to earn monopoly rents. It was measured by the eight largest firms' concentration ratios for their industries (their percentage of the sector's sales). Since unsuccessful firms are more likely to choose income increasing accounting procedures than their successful counterparts, PROFIT was also included as a control variable. PROFIT was measured as the earnings before interest and taxes for the financial year divided by the book value of assets. In addition, since inventory method choices could be affected by tax incentives, TAXRATE was included as a control variable. The TAXRATE is the firm's tax rate calculated by dividing the tax expense by net income before taxes. 


\section{Appendix 4: Multicollinearity in the logistic model}

The strong correlation between SALES and ASSETS (Kendall's tau-b $=0.722$ in the survey and 0.532 in the database) revealed the possibility that multi-collinearity could exist between these variables. No collinearity diagnostics are available from logistic regression in SPSS. However, since collinearity is solely a function of the independent variables, one could use linear regression to determine the extent to which collinearity is present.. Thus, one dependent ' $\mathrm{Y}$ ' variable was supplied and the same independent variables on the regression models statement that developed in the logistic model were tested. Ideally, the variance inflation factor (VIF) for each independent variable should be 1 (this would happen when variables in the model are orthogonal). Values of VIF exceeding 5 are often regarded as indicating multicollinearity, but in a weaker model, which is often the case in logistic regression, values above 2.5 may be a cause for concern. The VIF for SALES and ASSETS variables were 2.452 and 2.517 respectively for survey firms and 2.142 and 2.356 respectively for database firms. Thus, the standard error of the coefficient of the ASSETS variable for survey was larger than it would have been with in the absence of multicollinearity (values above 2.5) and the standard error of the coefficient of ASSETS variable for the database was very close to 2.5 . Since both SALES and ASSETS variables were used as alternative proxies for size, one of these two variables was dropped from the analysis. 
Table A3: Collinearity statistics

\begin{tabular}{|l|c|c|c|c|}
\hline \multirow{2}{*}{ Variable } & \multicolumn{2}{|c|}{ Survey } & \multicolumn{2}{c|}{ Database } \\
\cline { 2 - 5 } & Tolerance & VIF & Tolerance & VIF \\
\hline MP & 0.729 & 1.371 & 0.851 & 1.175 \\
LEV & 0.894 & 1.118 & 0.611 & 1.638 \\
LEVI & - & - & 0.660 & 1.514 \\
SALES & 0.408 & 2.452 & 0.467 & 2.142 \\
ASSETS & 0.397 & 2.517 & 0.424 & 2.356 \\
TAXRATE & 0.763 & 1.310 & 0.478 & 2.092 \\
BETA & - & - & 0.630 & 1.587 \\
CI & - & - & 0.637 & 1.570 \\
CR & - & - & 0.881 & 1.135 \\
PROFIT & - & - & 0.459 & 2.176 \\
\hline
\end{tabular}

Tolerance $=1 /$ VIF. These results are from an OLS regression of y-variable depreciation on all independent and control variables. 


\section{Appendix 5: Multivariate Statistical Analysis}

Table A4: Associations in the Logistic Analysis

\begin{tabular}{|c|c|c|c|c|}
\hline & \multicolumn{2}{|c|}{ DEP } & \multicolumn{2}{|c|}{ INV } \\
\hline & Value of B & p-value & Value of $B$ & p-value \\
\hline Survey: & & & & \\
\hline Bonus Scheme $\left(\mathrm{B}_{1}\right)$ & 3.653 & $0.0003 * *$ & 1.449 & $0.016^{*}$ \\
\hline Gearing $\left(\mathrm{B}_{2}\right)$ & 0.298 & 0.105 & 0.190 & 0.158 \\
\hline Database: & & & & \\
\hline Bonus Scheme $\left(\mathrm{B}_{1}\right)$ & 4.178 & $0.0001 * *$ & 2.273 & $0.016^{*}$ \\
\hline Gearing $\left(\mathrm{B}_{2}\right)$ & 0.037 & $0.033^{*}$ & 0.005 & 0.165 \\
\hline
\end{tabular}

